This document was prepared in conjunction with work accomplished under Contract No. DE-AC09-96SR18500 with the U. S. Department of Energy.

\title{
DISCLAIMER
}

This report was prepared as an account of work sponsored by an agency of the United States Government. Neither the United States Government nor any agency thereof, nor any of their employees, makes any warranty, express or implied, or assumes any legal liability or responsibility for the accuracy, completeness, or usefulness of any information, apparatus, product or process disclosed, or represents that its use would not infringe privately owned rights. Reference herein to any specific commercial product, process or service by trade name, trademark, manufacturer, or otherwise does not necessarily constitute or imply its endorsement, recommendation, or favoring by the United States Government or any agency thereof. The views and opinions of authors expressed herein do not necessarily state or reflect those of the United States Government or any agency thereof.

This report has been reproduced directly from the best available copy.

Available for sale to the public, in paper, from: U.S. Department of Commerce, National Technical Information Service, 5285 Port Royal Road, Springfield, VA 22161, phone: (800) 553-6847, fax: (703) 605-6900

email: orders@ntis.fedworld.gov

online ordering: http://www.ntis.gov/help/index.asp

Available electronically at http://www.osti.gov/bridge

Available for a processing fee to U.S. Department of Energy and its contractors, in paper, from: U.S. Department of Energy, Office of Scientific and Technical Information, P.O. Box 62, Oak Ridge, TN 37831-0062,

phone: (865)576-8401,

fax: (865)576-5728

email: $\underline{\text { reports@ adonis.osti.gov }}$ 


\section{Technical Basis for the Use of Alarming Personal Criticality Detectors to Augment Permanent Nuclear Incident Monitor (NIM) Systems in Areas Not Normally Occupied}




\section{Table of Contents}

\begin{tabular}{|c|c|c|c|c|c|c|c|c|c|}
\hline Abstract & - & - & - & - & - & - & - & - & 3 \\
\hline 1.0 Introduction & - & - & - & - & - & - & - & - & 3 \\
\hline \multicolumn{9}{|c|}{ 2.0 Technical Basis \& Minimum DOE O 420.1A and ANSI/ANS-8.3-1997 Requirements } & \\
\hline \multicolumn{4}{|c|}{ for APCDs Defined as Portable Instruments } & - & - & - & - & - & 4 \\
\hline \multicolumn{4}{|c|}{ 3.0 Definition of Not Normally Occupied } & - & - & - & - & - & 24 \\
\hline \multicolumn{6}{|c|}{ 4.0 APCD Design Criteria and APCDs that Meet the Criteria } & - & - & - & \\
\hline \multicolumn{4}{|c|}{ Requirements for APCD } & - & - & - & - & - & \\
\hline 6.0 References & - & - & - & - & - & - & - & - & \\
\hline Appendix A - WSR & sting & iem & PD-N & $\mathrm{CD}$ & - & - & - & - & \\
\hline
\end{tabular}

\section{List of Tables}

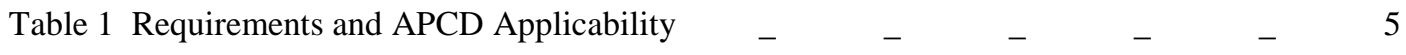

Table 2 APCD Design Criteria \& Siemens EPD/MK-2 and EPD-N Compliance _ _ $\quad 24$

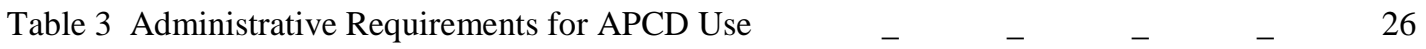




\begin{abstract}
The technical basis for the use of alarming personal criticality detectors (APCDs) to augment permanent Nuclear Incident Monitor (NIM) Systems in areas not normally occupied is evaluated. All applicable DOE O 420.1A and ANSI/ANS-8.3-1997 criticality alarm system requirements and recommendations are evaluated for applicability to APCDs. Based on this evaluation, design criteria and administrative requirements are presented for APCDs. Siemens EPD/Mk-2 and EPD-N devices are shown to meet the design criteria. A definition of not normally occupied is also presented.
\end{abstract}

\title{
1.0 Introduction
}

Criticality Accident Alarm Systems (CAAS), designated Nuclear Incident Monitors (NIM) at Savannah River Site, are used to alert personnel in affected areas (12 rad zone) to a criticality accident so that appropriate protective measures can be taken to limit their exposure to radiation. In accordance with DOE O $420.1 \mathrm{~A}^{1}$, which is incorporated into the WSRC S/RID, permanent NIM installations are used to provide coverage for site areas that are within the $12 \mathrm{rad}$ zone of potential criticality accident locations.

DOE O 420.1A also mandates the use of ANSI/ANS-8.3-1997. Criticality Accident Alarm System, ${ }^{2}$ which is also incorporated into the WSRC S/RID. ANSI/ANS-8.3-1997, para. 4.4.2 states:

\section{Portable instruments may be used in special situations to augment an installed criticality accident alarm system. Examples of such situations include alarm system maintenance or testing, evacuation drills, activities in areas not normally occupied by personnel, or other special operations. Where portable instruments are used to meet the intent of this standard, the usage shall be evaluated to determine appropriate criteria of this standard. Criteria for use of portable instruments shall be specified in procedures.}

This report specifically deals with augmentation of permanent NIM systems by the use of portable instruments in areas not normally occupied by personnel. That is, in areas defined as "not normally occupied", a portable instrument could be used instead of expanding the permanent NIM system into the area not normally occupied. A Group to Recommend Alternatives to NIM Detectors (GRAND) was formed in early 2003 to examine this specific form of NIM system augmentation. Members included:

R. M. Mobley, Mgr. Closure Eng/Safety Doc. \& Tech. Mgmt

P. K. Paul, H-Area Technical Support

J. W. McMahan, Operations, Maintenance Eng., Site NIM Engineer

D. Biswas, WSMS, Criticality and Radiation Transport

T. A. Reilly, WSMS, Criticality \& Radiation Transport

K. R. Yates, T\&QS, Nuclear Safety

Other situations given as examples in ANSI/ANS-8.3-1997, para. 4.4.2, were not examined by the group and are not dealt with in this report.

The purpose of this document is:

- $\quad$ to establish the technical basis and minimum requirements for Alarming Personal Criticality Detectors (APCD) to be defined as "portable instruments" (as used in ANSI/ANS-8.3-1997) to augment permanent NIM installations in facility areas not normally occupied;

- to define the term "not normally occupied";

- to provide specific APCD design criteria and document how specific APCDs meet the criteria;

- $\quad$ to provide administrative requirements for APCD usage in WSRC facilities;

Subsequent sections of the report deal with each of the aforementioned items. 


\subsection{Technical Basis \& Minimum DOE O 420.1A and ANSI/ANS-8.3-1997 Requirements for APCDs Defined as Portable Instruments}

DOE O 420.1A and ANSI/ANS-8.3-1997 requirements were reviewed for applicability for the use of APCDs as portable instruments as used in ANSI/ANS-8.3-1997, para. 4.4.2. Based on the review, compliance with all applicable requirements for portable criticality accident alarm systems is demonstrated. The review results are used in Section 4.0 of this report to establish APCD design criteria and to document how Siemens EPD/MK2 and EPD-N devices meet the criteria. The review results are also used in Section 5.0 to establish administrative requirements for APCD usage as portable instruments in areas not normally occupied in SRS Facilities.

Criticality accident alarm system requirements contained within DOE O 420.1A and ANSI/ANS-8.3-1997 are compiled in Table 1 and reviewed for their applicability to the use of APCDs as portable instruments. The first column of Table 1, labeled "Source", identifies the source document of each requirement. Column 2, labeled "Section", shows the section of the source document in which each requirement is located. Column 3 labeled "Requirement/Recommendation" contains each definition, requirement (shall), recommendation (should), and permission statement (may) from DOE O 420.1 A and ANSI/ANS-8.3-1997 that is applicable to a criticality accident alarm systems in general. Each definition, requirement, recommendation and permission statement is reviewed in column 4 labeled "APCD Requirement Applicability" for applicability to APCD usage as portable instruments. Columns 5 and 6, labeled "D" and "Ad" respectively, designates specific definitions, requirements, recommendations or permission statements as Design or Administrative requirements for APCDs used as portable instruments in areas not normally occupied. Column 7 contains the appropriate design criterion or administrative requirement statement as it pertains to APCDs. 
Table 1. Requirements and APCD Applicability

\begin{tabular}{|c|c|c|c|c|c|c|}
\hline Source & Section & Requirement / Recommendation & APCD Requirement Applicability & a & 安 & APCD Requirement \\
\hline \begin{tabular}{|l|} 
ANSI/ANS- \\
8.3 (1997)
\end{tabular} & 1 & $\begin{array}{l}\text { Where a criticality accident may lead to an excessive } \\
\text { radiation dose, it is important to provide a means of } \\
\text { alerting personnel and a procedure for their prompt } \\
\text { evacuation, or other protective actions to limit their } \\
\text { exposure. }\end{array}$ & $\begin{array}{l}\text { This statement is an introduction to discuss the purpose of } \\
\text { the standard. While applicable, it does not contain specific } \\
\text { requirements for the use of APCD as portable instruments in } \\
\text { areas not normally occupied by personnel. }\end{array}$ & N/A & N/A & N/A \\
\hline \begin{tabular}{|l|} 
ANSI/ANS- \\
8.3 (1997) \\
\end{tabular} & 2, part 1 & $\begin{array}{l}\text { This standard is applicable to all operations } \\
\text { involving fissionable materials in which inadvertent } \\
\text { criticality can occur and cause personnel to receive } \\
\text { unacceptable exposure to radiation. }\end{array}$ & $\begin{array}{l}\text { This is a general scope statement and is applicable to } \\
\text { APCDs used to augment NIMs in areas not normally } \\
\text { occupied. While applicable, it does not contain specific } \\
\text { requirements. }\end{array}$ & N/A & N/A & N/A \\
\hline $\begin{array}{l}\text { ANSI/ANS- } \\
8.3 \text { (1997) }\end{array}$ & 2, part 2 & $\begin{array}{l}\text { This standard is not applicable to detection of } \\
\text { criticality events where no excessive exposure to } \\
\text { personnel is credible, nor to nuclear reactors or } \\
\text { critical experiments. This standard does not include } \\
\text { details of administrative actions or of emergency } \\
\text { response actions that occur after alarm activation. }\end{array}$ & $\begin{array}{l}\text { This statement discusses the general scope of the standard, } \\
\text { is applicable to facilities in which APCDs are used to } \\
\text { augment NIMs in areas not normally occupied, but does not } \\
\text { contain any requirements. An explicit definition for } \\
\text { "excessive exposure" is not provided, therefore it is } \\
\text { presumed that "excessive exposure" and "excessive } \\
\text { radiation dose" are equivalent (i.e., } 12 \text { rad in free air). }\end{array}$ & N/A & N/A & N/A \\
\hline $\begin{array}{l}\text { ANSI/ANS- } \\
8.3(1997)\end{array}$ & 3.2, part 1 & $\begin{array}{l}\text { The word "shall" is used to denote a requirement, } \\
\text { the word "should" is used to denote a } \\
\text { recommendation, and the word "may" to denote } \\
\text { permission, neither a requirement nor a } \\
\text { recommendation. }\end{array}$ & $\begin{array}{l}\text { This statement discusses the general scope of the standard, } \\
\text { is applicable to APCDs used to augment NIMs in areas not } \\
\text { normally occupied, but does not contain any requirements. } \\
\text { Each "shall", "should", and "may" annotations are provided } \\
\text { in this table and examined for their applicability and } \\
\text { influence on the use of APCDs to augment NIMs. }\end{array}$ & N/A & N/A & N/A \\
\hline \begin{tabular}{|l|} 
ANSI/ANS- \\
8.3 (1997)
\end{tabular} & 3.2, part 2 & $\begin{array}{l}\text { To conform with this standard, all operations shall } \\
\text { be performed in accordance with its requirements } \\
\text { but not necessarily its recommendations. }\end{array}$ & $\begin{array}{l}\text { This statement discusses the general scope of the standard, } \\
\text { is applicable to APCDs, but does not contain any } \\
\text { requirements. Each "shall", "should", and "may" } \\
\text { annotations are provided in this table and examined for their } \\
\text { applicability on the use of APCDs to augment NIMs. }\end{array}$ & N/A & N/A & N/A \\
\hline $\begin{array}{l}\text { DOE O } \\
420.1 \mathrm{~A}\end{array}$ & 4.3.3.c & $\begin{array}{l}\text { All recommendations in the ANSI/ANS standards } \\
\text { (ANSI/ANS-8.3) shall be addressed. When } \\
\text { recommendations are not implemented, justification } \\
\text { shall be documented in a manner described in the } \\
\text { Implementation Plan. }\end{array}$ & $\begin{array}{l}\text { This requirement is applicable to APCDs used to augment } \\
\text { NIMs. Recommendations are either implemented or } \\
\text { justification is provided in this document. Each specific } \\
\text { recommendation associated with ANSI/ANS-8.3-1997 is } \\
\text { individually addressed in this document. }\end{array}$ & N/A & N/A & N/A \\
\hline
\end{tabular}




\begin{tabular}{|c|c|c|c|c|c|c|}
\hline Source & Section & Requirement / Recommendation & APCD Requirement Applicability & a & $\bar{z}$ & APCD Requirement \\
\hline $\begin{array}{l}\text { ANSI/ANS- } \\
8.3 \text { (1997) }\end{array}$ & 3.3, part 1 & $\begin{array}{l}\text { Definition: criticality accident } \\
\text { The release of energy as a result of accidental } \\
\text { production of a self-sustaining or divergent neutron } \\
\text { chain reaction. }\end{array}$ & $\begin{array}{l}\text { This definition is applicable to APCDs used to augment } \\
\text { NIMs, but does not contain specific requirements. }\end{array}$ & N/A & N/A & N/A \\
\hline $\begin{array}{l}\text { ANSI/ANS- } \\
8.3 \text { (1997) }\end{array}$ & 3.3, part 2 & $\begin{array}{l}\text { Definition: excessive radiation dose } \\
\text { Any dose to personnel corresponding to an absorbed } \\
\text { dose from neutrons and gamma rays equal to or } \\
\text { greater than } 0.12 \mathrm{~Gy}(12 \mathrm{rad}) \text { in free air. }\end{array}$ & $\begin{array}{l}\text { This definition is applicable to APCDs used to augment } \\
\text { NIMs, but does not contain specific requirements. The } 12 \\
\text { rad boundary is determined for a postulated criticality } \\
\text { accident corresponding to the maximum fission yield. This } \\
\text { boundary is not determined by this document. }\end{array}$ & N/A & N/A & N/A \\
\hline $\begin{array}{l}\text { ANSI/ANS- } \\
8.3 \text { (1997) }\end{array}$ & 3.3 , part 3 & $\begin{array}{l}\text { Definition: minimum accident of concern } \\
\text { The smallest accident, in terms of fission yield and } \\
\text { dose rate, that a criticality alarm system is required } \\
\text { to detect. }\end{array}$ & $\begin{array}{l}\text { This definition is applicable to APCDs used to augment } \\
\text { NIMs in areas not normally occupied, but only in a limited } \\
\text { sense. The minimum accident of concern in terms of fission } \\
\text { yield and translated into a constant dose rate is important to } \\
\text { fixed NIM detectors that cover a large area. However, } \\
\text { APCDs are worn on the individual and are only required to } \\
\text { cover the individual. By setting the APCD cumulative dose } \\
\text { alarm only high enough above background to prevent false } \\
\text { alarms, it will (by definition) detect what amounts to a } \\
\text { minimum accident of concern. }\end{array}$ & N/A & Ad & $\begin{array}{l}\text { The APCD cumulative dose alarm } \\
\text { shall be set high enough to avoid false } \\
\text { alarms while retaining the capability } \\
\text { to detect unsafe doses to workers }\end{array}$ \\
\hline $\begin{array}{l}\text { ANSI/ANS- } \\
8.3 \text { (1997) }\end{array}$ & 4.1 .1 & $\begin{array}{l}\text { Installation of an alarm system implies a nontrivial } \\
\text { risk of criticality. Where alarm systems are } \\
\text { installed, emergency procedures shall be maintained. }\end{array}$ & $\begin{array}{l}\text { This requirement is applicable to installed NIM systems and } \\
\text { indirectly to APCDs. Since APCDs are only used to } \\
\text { augment installed NIM systems in areas not normally } \\
\text { occupied, emergency procedures will be maintained because } \\
\text { of the regular installed NIM system }\end{array}$ & N/A & N/A & N/A \\
\hline $\begin{array}{l}\text { ANSI/ANS- } \\
8.3 \text { (1997) }\end{array}$ & 4.1 .2 & $\begin{array}{l}\text { Process equipment used in areas from which } \\
\text { immediate evacuation is required should be so } \\
\text { designed that leaving the equipment will not } \\
\text { introduce significant risk. }\end{array}$ & $\begin{array}{l}\text { This recommendation was reviewed during the } 5480.24 \\
\text { compliance assessment performed in } 1993 \text {. No process } \\
\text { equipment was identified at that time that would result in } \\
\text { significant risk if left unattended due to immediate facility } \\
\text { evacuation, and no new equipment has been introduced } \\
\text { since that time that would change the } 1993 \text { assessment; } \\
\text { hence this requirement is not applicable to APCDs. }\end{array}$ & N/A & N/A & N/A \\
\hline
\end{tabular}




\begin{tabular}{|c|c|c|c|c|c|c|}
\hline Source & Section & Requirement / Recommendation & APCD Requirement Applicability & a & $\frac{\pi}{4}$ & APCD Requirement \\
\hline $\begin{array}{l}\text { DOE O } \\
420.1 \mathrm{~A}\end{array}$ & 4.3.3.c & $\begin{array}{l}\text { ANSI/ANS-8.3-1986, paragraph 4.1.2, the second } \\
\text { sentence of which becomes for this Order, "Where } \\
\text { alarm systems are installed, emergency plans shall be } \\
\text { maintained." }\end{array}$ & $\begin{array}{l}\text { This requirement was addressed in ANSI/ANS-8.3-1997, } \\
\text { Section 4.1.1, above. }\end{array}$ & N/A & N/A & N/A \\
\hline $\begin{array}{l}\text { ANSI/ANS- } \\
8.3 \text { (1997) }\end{array}$ & 4.1.3, part 1 & $\begin{array}{l}\text { The purpose of an alarm system is to reduce risk to } \\
\text { personnel. }\end{array}$ & $\begin{array}{l}\text { This "purpose" statement is applicable to APCDs, but does } \\
\text { not contain specific requirements. }\end{array}$ & N/A & N/A & N/A \\
\hline \multirow[t]{2}{*}{$\begin{array}{l}\text { ANSI/ANS- } \\
8.3 \text { (1997) }\end{array}$} & \multirow[t]{2}{*}{ 4.1.3, part 2} & \multirow{2}{*}{$\begin{array}{l}\text { Evaluation of the overall risk should recognize that } \\
\text { hazards may result from false alarms and subsequent } \\
\text { sudden interruption of operations and relocation of } \\
\text { personnel. }\end{array}$} & \multirow{2}{*}{$\begin{array}{l}\text { This recommendation is applicable to APCDs used to } \\
\text { augment NIM systems in areas not normally occupied. The } \\
\text { APCD alarm setpoints for dose and dose rate must be } \\
\text { established in a manner that minimizes false alarms. The } \\
\text { APCD itself must also resist other causes of false alarms } \\
\text { such as radio frequency or electrostatic interference. }\end{array}$} & N/A & Ad & $\begin{array}{l}\text { The APCD alarm setpoints should be } \\
\text { set sufficiently above background to } \\
\text { minimize false alarms. }\end{array}$ \\
\hline & & & & $\mathrm{D}$ & N/A & $\begin{array}{l}\text { APCD should resist radio frequency } \\
\text { or electrostatic interference. }\end{array}$ \\
\hline $\begin{array}{l}\text { ANSI/ANS- } \\
8.3(1997)\end{array}$ & 4.2.1, part 1 & $\begin{array}{l}\text { The need for criticality alarm systems shall be } \\
\text { evaluated for all activities in which the inventory of } \\
\text { fissionable materials in individual unrelated areas } \\
\text { exceeds } 700 \mathrm{~g} \text { of } \mathrm{U}-235,500 \mathrm{~g} \text { of } \mathrm{U}-233,450 \mathrm{~g} \text { of } \\
\mathrm{Pu}-239 \text {, or } 450 \mathrm{~g} \text { of any combination of these three } \\
\text { isotopes. }\end{array}$ & $\begin{array}{l}\text { The mass values cited in paragraph } 4.2 .1 \text { of ANSI/ANS-8.3- } \\
1997 \text { are treated under DOE O } 420.1 \mathrm{~A} \text { with additional } \\
\text { specifications. Refer to the requirements of Section 4.3.3.e } \\
\text { of DOE O 420.1A, below. If a criticality accident alarm } \\
\text { system is needed, an APCD may be used in areas not } \\
\text { normally occupied to augment the regular NIM system. }\end{array}$ & N/A & N/A & N/A \\
\hline $\begin{array}{l}\text { ANSI/ANS- } \\
8.3 \text { (1997) }\end{array}$ & 4.2 .1$, part 2 & $\begin{array}{l}\text { For operations involving significant quantities of } \\
\text { other fissionable isotopes, this evaluation shall be } \\
\text { made whenever quantities exceed the subcritical } \\
\text { mass limits specified in American National Standard } \\
\text { Nuclear Criticality Control of Special Actinide } \\
\text { Elements, ANSI/ANS-8.15-1981 (R1995). }\end{array}$ & $\begin{array}{l}\text { The mass values cited in paragraph 4.2.1 of ANSI/ANS-8.3- } \\
1997 \text { are applicable under DOE O 420.1 A with additional } \\
\text { specifications. If a criticality accident alarm system is } \\
\text { needed, an APCD may be used in areas not normally } \\
\text { occupied to augment the regular NIM system. }\end{array}$ & N/A & N/A & N/A \\
\hline $\begin{array}{l}\text { ANSI/ANS- } \\
8.3 \text { (1997) }\end{array}$ & 4.2 .1$, part 3 & $\begin{array}{l}\text { Also, this evaluation shall be made for all processes } \\
\text { in which neutron moderators or reflectors more } \\
\text { effective than water are present, or unique material } \\
\text { configurations exist such that critical mass } \\
\text { requirements may be less than the typical subcritical } \\
\text { mass limits noted above. }\end{array}$ & $\begin{array}{l}\text { Paragraph } 4.2 .1 \text { of ANSI/ANS-8.3-1997 is applicable under } \\
\text { DOE O 420.1A with additional specifications. If a criticality } \\
\text { accident alarm system is needed because moderators more } \\
\text { effective than water are in use, an APCD may be used in } \\
\text { areas not normally occupied to augment the regular NIM } \\
\text { system. }\end{array}$ & N/A & N/A & N/A \\
\hline
\end{tabular}


WESTINGHOUSE SAVANNAH RIVER COMPANY T\&QS/NUCLEAR SAFETY
N-TRT-G-00001

Rev. 0

Page 8 of 29

\begin{tabular}{|c|c|c|c|c|c|c|}
\hline Source & Section & Requirement / Recommendation & APCD Requirement Applicability & a & \& & APCD Requirement \\
\hline $\begin{array}{l}\text { ANSI/ANS- } \\
8.3 \text { (1997) }\end{array}$ & 4.2 .1 , part 4 & $\begin{array}{l}\text { For this evaluation, individual areas may be } \\
\text { considered unrelated when the boundaries between } \\
\text { the areas are such that there can be no uncontrolled } \\
\text { transfer of materials between areas, the minimum } \\
\text { separation between material in adjacent areas is } 10 \\
\mathrm{~cm} \text {, and the areal density of fissile material averaged } \\
\text { over each individual area is less than } 50 \mathrm{~g} / \mathrm{m}^{2} \text {. This } \\
\text { stipulation is applicable only to the three specific } \\
\text { isotopes noted above (U-235, U- } 233 \text { and } \mathrm{Pu}-239) \text {. }\end{array}$ & $\begin{array}{l}\text { Paragraph 4.2.1 part } 4 \text { of ANSI/ANS-8.3-1997 is applicable } \\
\text { under DOE O 420.1A with additional specifications. Refer } \\
\text { to the requirements of Section 4.3.3.e of DOE O 420.1A, } \\
\text { below. If a criticality accident alarm system is needed, an } \\
\text { APCD may be used in areas not normally occupied to } \\
\text { augment the regular NIM system. }\end{array}$ & N/A & N/A & N/A \\
\hline $\begin{array}{l}\text { DOE O } \\
420.1 \mathrm{~A}\end{array}$ & 4.3.3.e & $\begin{array}{l}\text { The requirements in ANSI/ANS-8.3-1986 relating to } \\
\text { the needs for an alarm system (paragraphs } 4.2 .1 \text { and } \\
\text { 4.2.2), are not applicable to this Order. For the } \\
\text { purpose of this Order, Criticality Accident Alarm } \\
\text { Systems (CAS) and Criticality Detection Systems } \\
\text { (CDS) shall be required as follows: } \\
\text { In what follows, } 10^{-6} \text { per year is used as a measure of } \\
\text { credibility, and does not mean that probabilistic risk } \\
\text { assessment (PRA) has to be performed. Reasonable } \\
\text { grounds for incredibility may be presented on the } \\
\text { basis of commonly accepted engineering judgment. }\end{array}$ & $\begin{array}{l}\text { This DOE O 420.1A requirement is applicable to APCDs } \\
\text { used to augment NIMs in areas not normally occupied, but } \\
\text { no specific requirements for APCDs are required. }\end{array}$ & N/A & N/A & N/A \\
\hline
\end{tabular}


WESTINGHOUSE SAVANNAH RIVER COMPANY T\&QS/NUCLEAR SAFETY
N-TRT-G-00001

Rev. 0

Page 9 of 29

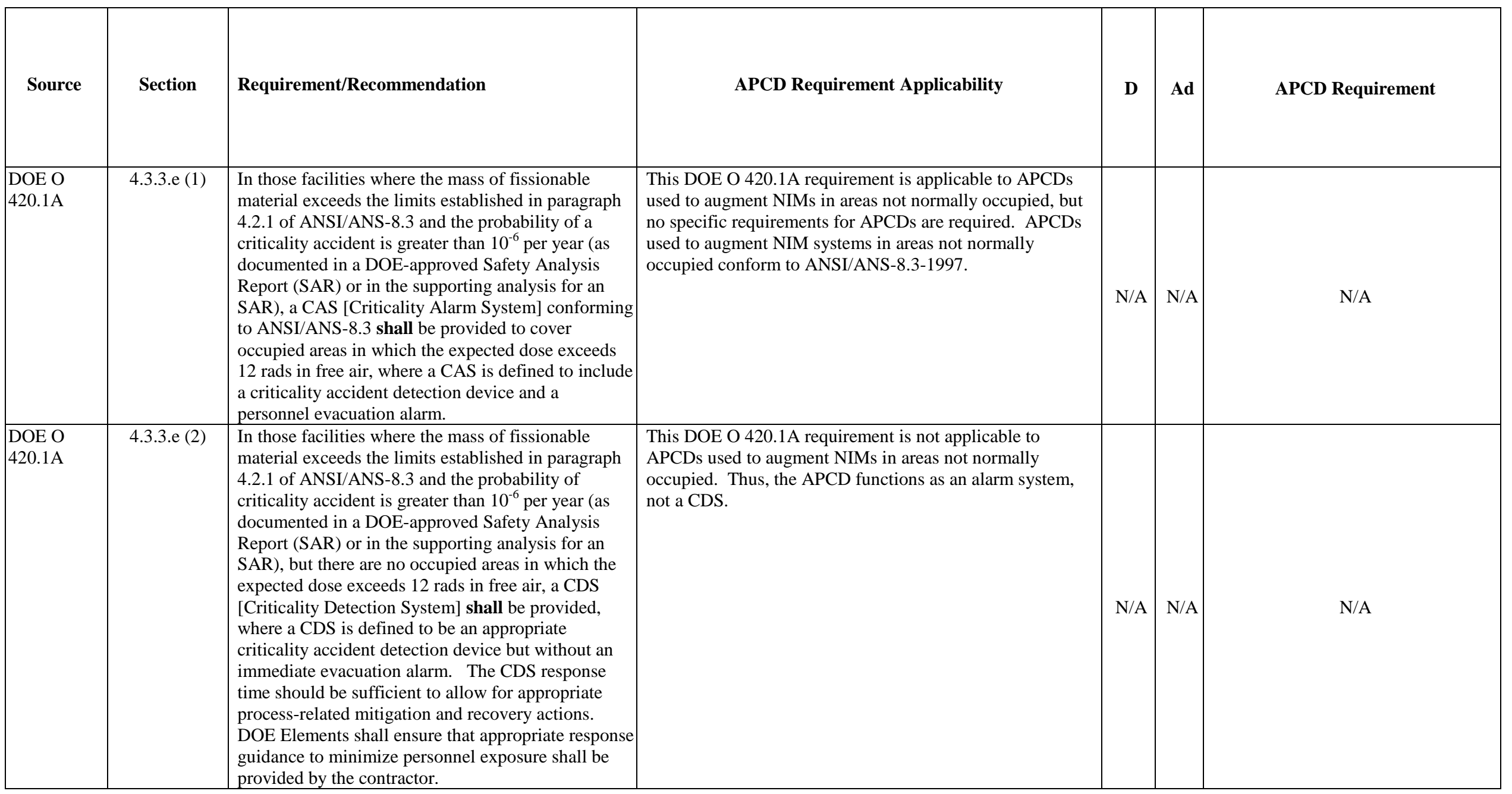


WESTINGHOUSE SAVANNAH RIVER COMPANY T\&QS/NUCLEAR SAFETY
N-TRT-G-00001

Rev. 0

Page 10 of 29

\begin{tabular}{|c|c|c|c|c|c|c|}
\hline Source & Section & Requirement/Recommendation & APCD Requirement Applicability & D & Ad & APCD Requirement \\
\hline $\begin{array}{l}\text { DOE O } \\
420.1 \mathrm{~A}\end{array}$ & 4.3.3.e (3) & $\begin{array}{l}\text { In those facilities where the mass of fissionable } \\
\text { material exceeds the limits established in paragraph } \\
4.2 .1 \text { of ANSI/ANS-8.3, but a criticality accident is } \\
\text { determined to be impossible due to the physical form } \\
\text { of the fissionable material, or the probability of } \\
\text { occurrence is determined to be less than } 10^{-6} \text { per year } \\
\text { (as documented in a DOE-approved Safety Analysis } \\
\text { Report (SAR) or in the supporting analysis for an } \\
\text { SAR, or in other appropriate documentation), neither } \\
\text { a CAS nor a CDS is required. } \\
\text { Neither a CAS nor a CDS is required for fissionable } \\
\text { material during shipment when packaged in } \\
\text { approved shipping containers, or when packaged in } \\
\text { approved shipping containers awaiting transport } \\
\text { provided that no other operation involving } \\
\text { fissionable material not so packaged is permitted on } \\
\text { the shipping dock or in the shipment area. }\end{array}$ & $\begin{array}{l}\text { This DOE O 420.1A statement is not applicable to APCDs. } \\
\text { If a NIM system is not necessary, APCD use is not } \\
\text { necessary. }\end{array}$ & N/A & N/A & N/A \\
\hline $\begin{array}{l}\text { ANSI/ANS- } \\
8.3 \text { (1997) }\end{array}$ & 4.2.2, part 1 & $\begin{array}{l}\text { A criticality alarm system meeting the requirements } \\
\text { of this standard shall be installed in areas where } \\
\text { personnel would be subject to an excessive radiation } \\
\text { dose. }\end{array}$ & $\begin{array}{l}\text { Paragraph 4.2.2 of ANSI/ANS-8.3-1997 is not applicable } \\
\text { under DOE O 420.1A. Refer to the requirements of Section } \\
\text { 4.3.3.e of DOE O 420.1A instead. }\end{array}$ & N/A & N/A & N/A \\
\hline $\begin{array}{l}\text { ANSI/ANS- } \\
8.3 \text { (1997) }\end{array}$ & 4.2.2, part 2 & $\begin{array}{l}\text { For this purpose, the maximum fission yield } \\
\text { integrated over the duration of the accident may be } \\
\text { assumed not to exceed } 2.0 \times 10^{19} \text { fissions. The basis } \\
\text { for a different maximum fission yield shall be } \\
\text { documented. }\end{array}$ & $\begin{array}{l}\text { Paragraph } 4.2 .2 \text { of ANSI/ANS-8.3-1997 is not applicable } \\
\text { under DOE O } 420.1 \mathrm{~A} \text {. However, this permission and } \\
\text { requirement statement provides a reasonable basis for } \\
\text { evaluating the need for a NIM, and hence APCDs used to } \\
\text { augment NIMs. There are no specific requirements relative } \\
\text { to APCDs. Determination of the maximum fission yield and } \\
\text { corresponding } 12 \text { rad boundary defines the area where } \\
\text { personnel may be subject to an excessive radiation dose. }\end{array}$ & N/A & N/A & N/A \\
\hline
\end{tabular}


WESTINGHOUSE SAVANNAH RIVER COMPANY T\&QS/NUCLEAR SAFETY
N-TRT-G-00001

Rev. 0

Page 11 of 29

\begin{tabular}{|c|c|c|c|c|c|c|}
\hline Source & Section & Requirement/Recommendation & APCD Requirement Applicability & D & Ad & APCD Requirement \\
\hline \multirow[t]{2}{*}{$\begin{array}{l}\text { DOE O } \\
420.1 \mathrm{~A}\end{array}$} & \multirow[t]{2}{*}{$\begin{array}{l}\text { 4.3.3.e (4) } \\
\text { (continued) }\end{array}$} & \multirow{2}{*}{$\begin{array}{l}\text { To aid in protecting workers against the } \\
\text { consequences of slow criticality accidents in } \\
\text { facilities where analysis has shown that slow } \\
\text { criticality accidents are credible, CASs should be } \\
\text { supplemented by warning devices such as audible } \\
\text { personnel dosimeters (e.g. pocket chirpers/flashers, } \\
\text { or their equivalents), area radiation monitors, area } \\
\text { dosimeters, or integrating CASs. If these devices are } \\
\text { used solely as criticality warning devices in } \\
\text { accordance with this Section, the calibration } \\
\text { provisions required for personal protection do not } \\
\text { apply (10CFR835, 401(b)). }\end{array}$} & \multirow{2}{*}{$\begin{array}{l}\text { This DOE O 420.1A recommendation is applicable to } \\
\text { APCDs in areas not normally occupied since APCDs are } \\
\text { used as alarm systems. However, an APCD will alarm on } \\
\text { cumulative dose (as well as dose rate); therefore it meets the } \\
\text { requirement. Since an APCD will be used as an alarm } \\
\text { device (i.e., just like a NIM) and not as a warning device, } \\
\text { the statement regarding calibration is not applicable. }\end{array}$} & D & & $\begin{array}{l}\text { The APCD must be capable of } \\
\text { alarming on total dose. }\end{array}$ \\
\hline & & & & & Ad & $\begin{array}{l}\text { Normal Radcon calibration procedures } \\
\text { applicable to electronic personal } \\
\text { dosimeters will be applied to APCDs. }\end{array}$ \\
\hline
\end{tabular}


WESTINGHOUSE SAVANNAH RIVER COMPANY T\&QS/NUCLEAR SAFETY
N-TRT-G-00001

Rev. 0

Page 12 of 29

\begin{tabular}{|c|c|c|c|c|c|c|}
\hline Source & Section & Requirement/Recommendation & APCD Requirement Applicability & D & Ad & APCD Requirement \\
\hline \multirow[t]{4}{*}{$\begin{array}{l}\text { ANSI/ANS- } \\
8.3 \text { (1997) }\end{array}$} & \multirow[t]{4}{*}{ 4.3.1, part 1} & \multirow[t]{4}{*}{$\begin{array}{l}\text { Criticality alarm signals shall be for prompt } \\
\text { evacuation or other protective actions. }\end{array}$} & \multirow[t]{4}{*}{$\begin{array}{l}\text { This requirement is applicable to APCDs used to augment } \\
\text { NIMs in areas not normally occupied. APCDs provide a } \\
\text { local alarm signal to the wearer. Upon APCD alarm, prompt } \\
\text { evacuation will be required. }\end{array}$} & $\mathrm{D}$ & N/A & $\begin{array}{l}\text { APCDs shall provide a signal to the } \\
\text { individual carrying the instrument } \\
\text { that is recognizable as one that } \\
\text { requires prompt evacuation. }\end{array}$ \\
\hline & & & & N/A & Ad & $\begin{array}{l}\text { Facilities/projects utilizing APCDs } \\
\text { shall have an approved training } \\
\text { program/procedure on APCD use. }\end{array}$ \\
\hline & & & & N/A & $\mathrm{Ad}$ & $\begin{array}{l}\text { Personnel wearing APCDs shall be } \\
\text { trained in their use and in evacuation. }\end{array}$ \\
\hline & & & & N/A & Ad & $\begin{array}{l}\text { If protective actions in addition to } \\
\text { evacuation are necessary, they also } \\
\text { shall be specified in training. }\end{array}$ \\
\hline \multirow[t]{2}{*}{$\begin{array}{l}\text { ANSI/ANS- } \\
8.3 \text { (1997) }\end{array}$} & \multirow[t]{2}{*}{ 4.3.1, part 2} & \multirow[t]{2}{*}{$\begin{array}{l}\text { The criticality alarm signals should be uniform } \\
\text { throughout the system. }\end{array}$} & \multirow{2}{*}{$\begin{array}{l}\text { This recommendation is applicable to APCDs used to } \\
\text { augment NIM systems in areas not normally occupied. } \\
\text { However, by design, the APCDs provide a local audio } \\
\text { signal to the wearer different than installed NIM units. } \\
\text { Personnel training on the APCD alarm sound must be } \\
\text { provided. }\end{array}$} & $\mathrm{D}$ & N/A & $\begin{array}{l}\text { APCDs shall provide a signal to the } \\
\text { individual carrying the instrument } \\
\text { that is recognizable as a criticality } \\
\text { alarm requiring prompt evacuation. }\end{array}$ \\
\hline & & & & N/A & $\mathrm{Ad}$ & $\begin{array}{l}\text { Personnel wearing APCDs shall be } \\
\text { trained in their use. }\end{array}$ \\
\hline
\end{tabular}




\begin{tabular}{|c|c|c|c|c|c|c|}
\hline Source & Section & Requirement/Recommendation & APCD Requirement Applicability & D & Ad & APCD Requirement \\
\hline \multirow[t]{3}{*}{$\begin{array}{l}\text { ANSI/ANS- } \\
8.3 \text { (1997) }\end{array}$} & \multirow[t]{3}{*}{ 4.3.1, part 3} & \multirow[t]{3}{*}{$\begin{array}{l}\text { The signals shall be distinctive from other signals or } \\
\text { alarms that require a response different from that } \\
\text { necessary in the event of a criticality accident. }\end{array}$} & \multirow[t]{3}{*}{$\begin{array}{l}\text { This requirement is applicable to APCDs used to augment } \\
\text { NIMs. APCDs provide a local alarm signal to the wearer } \\
\text { that is distinctive from non-NIM signals that may be present } \\
\text { in the work area. }\end{array}$} & D & N/A & $\begin{array}{l}\text { APCDs shall provide a signal to the } \\
\text { individual carrying the instrument } \\
\text { that is recognizable as criticality } \\
\text { alarm requiring prompt evacuation. }\end{array}$ \\
\hline & & & & N/A & Ad & $\begin{array}{l}\text { Personnel wearing APCDs shall be } \\
\text { trained in their use. }\end{array}$ \\
\hline & & & & N/A & Ad & $\begin{array}{l}\text { Personnel shall be capable of } \\
\text { distinguishing the APCD alarm from } \\
\text { other alarms. }\end{array}$ \\
\hline $\begin{array}{l}\text { ANSI/ANS- } \\
8.3 \text { (1997) }\end{array}$ & 4.3 .2 & $\begin{array}{l}\text { The signal generators shall be automatically and } \\
\text { promptly actuated upon detection of a criticality } \\
\text { accident. }\end{array}$ & $\begin{array}{l}\text { This requirement is applicable to APCDs used to augment } \\
\text { NIMs in areas not normally occupied. Tests shall confirm } \\
\text { that APCDs alarm promptly in dose rate and cumulative } \\
\text { dose modes. }\end{array}$ & $\mathrm{D}$ & N/A & $\begin{array}{l}\text { APCDs shall be tested to alarm } \\
\text { promptly and automatically to a } \\
\text { simulated criticality accident }\end{array}$ \\
\hline \multirow[t]{3}{*}{$\begin{array}{l}\text { ANSI/ANS- } \\
8.3 \text { (1997) }\end{array}$} & \multirow[t]{3}{*}{ 4.3.3, part 1} & \multirow[t]{3}{*}{$\begin{array}{l}\text { After actuation, the signal generators shall continue } \\
\text { to function as required by emergency procedures, } \\
\text { even if the radiation falls below the alarm point. }\end{array}$} & \multirow{3}{*}{$\begin{array}{l}\text { This requirement is applicable to APCDs used to augment } \\
\text { NIMs in areas not normally occupied, but only in a limited } \\
\text { sense. The continuous alarm signal generation function is } \\
\text { for regular NIMs to alert personnel in the area of the alarm } \\
\text { signal and to help preclude inadvertent entry of personnel } \\
\text { into a building shortly after the onset of an accident. By } \\
\text { maintaining the alarm condition, all personnel (by training } \\
\text { and evacuation procedures) are kept at a safe distance until } \\
\text { the source of the alarm is confirmed. } \\
\text { APCDs are local units worn only by personnel in areas not } \\
\text { normally occupied. Therefore, the APCD must alarm long } \\
\text { enough to clearly alert the user of the alarm condition. } \\
\text { Upon APCD alarm, personnel will be trained to } \\
\text { immediately evacuate the area not normally occupied and } \\
\text { then contact the appropriate control room. The control room } \\
\text { can then order any other emergency actions }\end{array}$} & $\mathrm{D}$ & N/A & $\begin{array}{l}\text { APCDs shall provide a signal to the } \\
\text { individual carrying the instrument that } \\
\text { is sufficiently long to get their } \\
\text { attention }\end{array}$ \\
\hline & & & & N/A & Ad & $\begin{array}{l}\text { Personnel wearing APCDs shall be } \\
\text { trained in their use, including the need } \\
\text { and method to contact the appropriate } \\
\text { control room after evacuation. }\end{array}$ \\
\hline & & & & N/A & Ad & $\begin{array}{l}\text { All individuals entering an area not } \\
\text { normally occupied shall be equipped } \\
\text { with an APCD. If only one person } \\
\text { enters such area, that person shall be } \\
\text { equipped with two APCDs }\end{array}$ \\
\hline
\end{tabular}


WESTINGHOUSE SAVANNAH RIVER COMPANY T\&QS/NUCLEAR SAFETY
N-TRT-G-00001

Rev. 0

Page 14 of 29

\begin{tabular}{|c|c|c|c|c|c|c|}
\hline Source & Section & Requirement/Recommendation & APCD Requirement Applicability & D & Ad & APCD Requirement \\
\hline $\begin{array}{l}\text { ANSI/ANS- } \\
8.3(1997)\end{array}$ & 4.3.3, part 2 & $\begin{array}{l}\text { Manual resets, with limited access, should be } \\
\text { provided outside areas that require evacuation. }\end{array}$ & $\begin{array}{l}\text { This recommendation is not applicable to APCD, but is for } \\
\text { the remote re-setting of fixed instruments. }\end{array}$ & N/A & N/A & N/A \\
\hline $\begin{array}{l}\text { ANSI/ANS- } \\
8.3 \text { (1997) }\end{array}$ & 4.3 .5 & $\begin{array}{l}\text { For all occupied areas where personnel protective } \\
\text { action is required in the event of criticality accident } \\
\text { detection, the number and placement of criticality } \\
\text { alarm signal generators shall be such that the signals } \\
\text { are adequate to notify personnel promptly } \\
\text { throughout those areas. }\end{array}$ & $\begin{array}{l}\text { This requirement is applicable to APCDs used to augment } \\
\text { NIMs in areas not normally occupied. When APCDs are } \\
\text { used to augment NIMs in areas not normally } \\
\text { occupied, each individual within the required } \\
\text { coverage area will be required to wear an APCD. } \\
\text { Additionally, APCD users will be required and trained to } \\
\text { contact the appropriate control room after evacuation. The } \\
\text { control room can then notify all necessary personnel. }\end{array}$ & N/A & Ad & $\begin{array}{l}\text { All individuals entering an area not } \\
\text { normally occupied shall be equipped } \\
\text { with an APCD. If only one person } \\
\text { enters such area, that person shall be } \\
\text { equipped with two APCDs }\end{array}$ \\
\hline & & & & N/A & Ad & $\begin{array}{l}\text { APCD users shall contact the } \\
\text { appropriate control room after } \\
\text { evacuation so that the event is logged } \\
\text { and other emergency actions taken as } \\
\text { necessary. }\end{array}$ \\
\hline $\begin{array}{l}\text { ANSI/ANS- } \\
8.3 \text { (1997) }\end{array}$ & 4.3 .6 & $\begin{array}{l}\text { The audio generators should produce an overall } \\
\text { sound pressure level of at least } 75 \mathrm{~dB} \text {, but not less } \\
\text { than } 10 \mathrm{~dB} \text { above the maximum ambient noise level } \\
\text { typical of each area for which audio coverage is to } \\
\text { be provided. }\end{array}$ & $\begin{array}{l}\text { This recommendation is applicable to APCDs in a limited } \\
\text { sense. APCDs are worn by individuals, Therefore, general } \\
\text { area sound pressure levels are not applicable. The APCD } \\
\text { audio alarm must be loud enough to be heard by the person } \\
\text { wearing the APCD. }\end{array}$ & $\mathrm{D}$ & N/A & $\begin{array}{l}\text { The APCD audio alarm shall be loud } \\
\text { enough to be heard by the individual } \\
\text { wearing the device. }\end{array}$ \\
\hline
\end{tabular}




\begin{tabular}{|c|c|c|c|c|c|c|}
\hline Source & Section & Requirement/Recommendation & APCD Requirement Applicability & D & Ad & APCD Requirement \\
\hline $\begin{array}{l}\text { ANSI/ANS- } \\
8.3(1997)\end{array}$ & 4.3 .7 & $\begin{array}{l}\text { Because excessive noise levels can be injurious to } \\
\text { personnel, the audio generators should not produce } \\
\text { an A-weighted sound level in excess of } 115 \mathrm{~dB} \text { at the } \\
\text { ear of an individual. }\end{array}$ & $\begin{array}{l}\text { This recommendation is applicable to APCDs in the sense } \\
\text { that the audio alarm should not cause hearing damage. }\end{array}$ & $\mathrm{D}$ & N/A & $\begin{array}{l}\text { APCD audio generator sound level } \\
\text { should not be loud enough to cause } \\
\text { hearing damage. }\end{array}$ \\
\hline \multirow[t]{2}{*}{$\begin{array}{l}\text { ANSI/ANS- } \\
8.3 \text { (1997) }\end{array}$} & \multirow[t]{2}{*}{4.3 .8} & \multirow[t]{2}{*}{$\begin{array}{l}\text { In areas with very high audio background or } \\
\text { mandatory hearing protection, visual signals or other } \\
\text { alarm means should be considered. }\end{array}$} & \multirow{2}{*}{$\begin{array}{l}\text { This recommendation is applicable to APCDs used to } \\
\text { augment NIMs in area not normally occupied. If APCDs are } \\
\text { used in areas of such high background noise that the alarm } \\
\text { cannot adequately be heard, they should be equipped with } \\
\text { an earpiece or vibration alarm. }\end{array}$} & N/A & Ad & $\begin{array}{l}\text { When using APCDs in high noise } \\
\text { areas, they should be equipped with } \\
\text { earpieces or vibration alarms. }\end{array}$ \\
\hline & & & & $\mathrm{D}$ & N/A & $\begin{array}{l}\text { APCDs should include the ability to } \\
\text { use earpieces or provide vibrations } \\
\text { alarms. }\end{array}$ \\
\hline \multirow[t]{2}{*}{$\begin{array}{l}\text { ANSI/ANS- } \\
8.3 \text { (1997) }\end{array}$} & \multirow[t]{2}{*}{ 4.4.1, part 1} & \multirow{2}{*}{$\begin{array}{l}\text { Consideration shall be given to the avoidance of } \\
\text { false alarms. This may be accomplished by } \\
\text { providing reliable single detector channels or by } \\
\text { requiring concurrent response of two or more } \\
\text { detectors to initiate the alarm. }\end{array}$} & \multirow{2}{*}{$\begin{array}{l}\text { This requirement is applicable to APCDs used to augment } \\
\text { NIMS in areas not normally occupied. Alarm setpoints shall } \\
\text { be chosen to minimize false alarms. If APCDs include pre- } \\
\text { alarms, they should be disabled. }\end{array}$} & N/A & Ad & $\begin{array}{l}\text { The APCD alarm setpoint should be } \\
\text { set sufficiently above background to } \\
\text { minimize false alarms. }\end{array}$ \\
\hline & & & & N/A & $\mathrm{Ad}$ & $\begin{array}{l}\text { APCD pre-alarms, if provided, should } \\
\text { be disabled. }\end{array}$ \\
\hline $\begin{array}{l}\text { ANSI/ANS- } \\
8.3(1997)\end{array}$ & 4.4.1, part 2 & $\begin{array}{l}\text { In redundant systems, failure of any single channel } \\
\text { shall not prevent compliance with the detection } \\
\text { criterion specified in 5.6. }\end{array}$ & $\begin{array}{l}\text { This requirement is applicable to APCDs used to augment } \\
\text { NIMs, but only in a limited sense. APCDs are not redundant } \\
\text { systems; however, the intent of the standard is met by } \\
\text { requiring a minimum of } 2 \text { APCDs in any area not normally } \\
\text { occupied. }\end{array}$ & N/A & Ad & $\begin{array}{l}\text { All individuals entering an area not } \\
\text { normally occupied shall be equipped } \\
\text { with an APCD. If only one person } \\
\text { enters such area, that person shall be } \\
\text { equipped with two APCDs } \\
\end{array}$ \\
\hline $\begin{array}{l}\text { ANSI/ANS- } \\
8.3 \text { (1997) }\end{array}$ & 4.4 .2$, part 1 & \begin{tabular}{|l|} 
Portable instruments may be used in special \\
situations to augment an installed criticality accident \\
alarm system. Examples of such situations include \\
alarm system maintenance or testing, evacuation \\
drills, activities in areas not normally occupied by \\
personnel, or other special operations. \\
\end{tabular} & $\begin{array}{l}\text { This permission allows the use of APCDs for special } \\
\text { situations and is applicable to APCDs. This document } \\
\text { provides the technical basis to allow APCDs to specifically } \\
\text { augment NIMs in areas not normally occupied. }\end{array}$ & N/A & Ad & $\begin{array}{l}\text { Documentation (this report) will be } \\
\text { prepared to justify the use of APCDs } \\
\text { to augment NIMs in areas not } \\
\text { normally occupied. }\end{array}$ \\
\hline $\begin{array}{l}\text { ANSI/ANS- } \\
8.3 \text { (1997) }\end{array}$ & 4.4 .2$, part 2 & $\begin{array}{l}\text { Where portable instruments are used to meet the } \\
\text { intent of this standard, the usage shall be evaluated } \\
\text { to determine appropriate criteria of this standard. }\end{array}$ & $\begin{array}{l}\text { This requirement allows the use of APCDs for specific } \\
\text { situations. This document provides the technical basis for } \\
\text { using APCDs to augment NIMs in areas not normally } \\
\text { occupied and identifies the criteria appropriate for such use. }\end{array}$ & N/A & Ad & $\begin{array}{l}\text { Documentation (this report) will be } \\
\text { prepared to justify the use of APCDs } \\
\text { to augment NIMs in areas not } \\
\text { normally occupied. }\end{array}$ \\
\hline
\end{tabular}


WESTINGHOUSE SAVANNAH RIVER COMPANY T\&QS/NUCLEAR SAFETY
N-TRT-G-00001

Rev. 0

Page 16 of 29

\begin{tabular}{|c|c|c|c|c|c|c|}
\hline Source & Section & Requirement/Recommendation & APCD Requirement Applicability & $\mathbf{D}$ & Ad & APCD Requirement \\
\hline $\begin{array}{l}\text { ANSI/ANS- } \\
8.3 \text { (1997) }\end{array}$ & 4.4 .2$, part 3 & $\begin{array}{l}\text { Criteria for such use of portable instruments shall be } \\
\text { specified in procedures. }\end{array}$ & $\begin{array}{l}\text { This requirement is applicable to APCDs used to augment } \\
\text { NIMs in areas not normally occupied. }\end{array}$ & N/A & Ad & $\begin{array}{l}\text { Facilities/Projects shall develop } \\
\text { procedures to ensure that the } \\
\text { requirements specified in this } \\
\text { document are met. }\end{array}$ \\
\hline \multirow[t]{3}{*}{$\begin{array}{l}\text { ANSI/ANS- } \\
8.3 \text { (1997) }\end{array}$} & \multirow[t]{3}{*}{4.4 .3} & \multirow{3}{*}{$\begin{array}{l}\text { Process areas in which activities will continue during } \\
\text { power outages shall have emergency power supplies } \\
\text { for alarm systems, or such activities shall be } \\
\text { monitored continuously with portable instruments. }\end{array}$} & \multirow{3}{*}{$\begin{array}{l}\text { This requirement is applicable to APCDs used to augment } \\
\text { NIMs in areas not normally occupied. APCDs are battery } \\
\text { powered and not susceptible to facility power outages. In } \\
\text { the event of low battery condition, personnel are trained to } \\
\text { evacuate the area. Batteries shall be changed or re-charged } \\
\text { on a regular basis. }\end{array}$} & $\mathrm{D}$ & N/A & $\begin{array}{l}\text { APCDs shall be capable of alerting } \\
\text { the user to a low battery condition. }\end{array}$ \\
\hline & & & & N/A & Ad & $\begin{array}{l}\text { Personnel shall be trained to evacuate } \\
\text { the area upon low battery condition. }\end{array}$ \\
\hline & & & & N/A & Ad & $\begin{array}{l}\text { Batteries shall be changed or re- } \\
\text { charged on a regular basis as } \\
\text { determined by the life of the battery. }\end{array}$ \\
\hline \multirow[t]{4}{*}{$\begin{array}{l}\text { ANSI/ANS- } \\
8.3 \text { (1997) }\end{array}$} & \multirow[t]{4}{*}{4.4 .4} & \multirow[t]{4}{*}{$\begin{array}{l}\text { The alarm system shall be sufficiently robust as to } \\
\text { actuate the alarm signal when exposed to the } \\
\text { maximum radiation expected. }\end{array}$} & \multirow{4}{*}{$\begin{array}{l}\text { This requirement is applicable APCDs used to augment } \\
\text { NIMs in areas not normally occupied. Previous testing of } \\
\text { various devices has demonstrated that some will not alarm if } \\
\text { within a few feet of a criticality accident. Tests shall } \\
\text { determine if there is some minimum APCD offset distance } \\
\text { from the edge of a criticality accident. }\end{array}$} & $\mathrm{D}$ & N/A & $\begin{array}{l}\text { APCDs shall be of a type that has } \\
\text { been tested to establish their } \\
\text { capability to alarm in radiation fields } \\
\text { typical of a criticality accident. }\end{array}$ \\
\hline & & & & N/A & Ad & $\begin{array}{l}\text { A minimum offset distance from the } \\
\text { edge of a criticality accident shall be } \\
\text { established as necessary to ensure } \\
\text { functionality of the APCD. }\end{array}$ \\
\hline & & & & N/A & Ad & $\begin{array}{l}\text { All individuals entering an area not } \\
\text { normally occupied shall be equipped } \\
\text { with an APCD. If only one person } \\
\text { enters such area, that person shall be } \\
\text { equipped with two APCDs }\end{array}$ \\
\hline & & & & N/A & Ad & $\begin{array}{l}\text { APCDs shall not be reused after } \\
\text { exposure to excessive radiation fields. }\end{array}$ \\
\hline
\end{tabular}


WESTINGHOUSE SAVANNAH RIVER COMPANY T\&QS/NUCLEAR SAFETY
N-TRT-G-00001

Rev. 0

Page 17 of 29

\begin{tabular}{|c|c|c|c|c|c|c|}
\hline Source & Section & Requirement/Recommendation & APCD Requirement Applicability & D & Ad & APCD Requirement \\
\hline \multirow[t]{3}{*}{$\begin{array}{l}\text { ANSI/ANS- } \\
8.3 \text { (1997) }\end{array}$} & \multirow[t]{3}{*}{5.1, part 1} & \multirow[t]{3}{*}{ The system shall be designed for high reliability. } & \multirow[t]{3}{*}{$\begin{array}{l}\text { This requirement is applicable to APCDs used to augment } \\
\text { NIMs in areas not normally occupied. }\end{array}$} & $\mathrm{D}$ & N/A & $\begin{array}{l}\text { APCDs shall be of a type that has } \\
\text { been tested to establish their } \\
\text { capability to alarm in radiation fields } \\
\text { typical of a criticality accident. }\end{array}$ \\
\hline & & & & NA & Ad & $\begin{array}{l}\text { APCDs shall be periodically } \\
\text { calibrated and tested to ensure } \\
\text { functionality and reliability. }\end{array}$ \\
\hline & & & & N/A & Ad & $\begin{array}{l}\text { APCDs shall not be reused after } \\
\text { exposure to excessive radiation fields. }\end{array}$ \\
\hline $\begin{array}{l}\text { ANSI/ANS- } \\
8.3 \text { (1997) }\end{array}$ & 5.1 , part 2 & $\begin{array}{l}\text { The system should utilize components that do not } \\
\text { require frequent servicing, such as lubrication or } \\
\text { cleaning. }\end{array}$ & $\begin{array}{l}\text { This recommendation is applicable to APCDs used to } \\
\text { augment NIMs in areas not normally occupied. }\end{array}$ & $\mathrm{D}$ & N/A & $\begin{array}{l}\text { APCDs should be of a type that does } \\
\text { not require frequent servicing, } \\
\text { lubrication, or cleaning. }\end{array}$ \\
\hline \multirow[t]{2}{*}{$\begin{array}{l}\text { ANSI/ANS- } \\
8.3 \text { (1997) }\end{array}$} & \multirow[t]{2}{*}{5.1 , part 3} & \multirow[t]{2}{*}{$\begin{array}{l}\text { The system should be designed to minimize the } \\
\text { effects of non-use, deterioration, power surges, and } \\
\text { other adverse conditions. }\end{array}$} & \multirow[t]{2}{*}{$\begin{array}{l}\text { This recommendation is applicable to APCDs used to } \\
\text { augment NIMs in areas not normally occupied. Since } \\
\text { APCDs are battery powered, power surges are not a } \\
\text { problem. }\end{array}$} & $\mathrm{D}$ & N/A & $\begin{array}{l}\text { APCDs should be designed to } \\
\text { minimize the effects of non-use, } \\
\text { deterioration, and other adverse } \\
\text { conditions (e.g., RF interference). }\end{array}$ \\
\hline & & & & NA & Ad & $\begin{array}{l}\text { APCDs shall be calibrated and tested } \\
\text { periodically to ensure functionality } \\
\text { and reliability. }\end{array}$ \\
\hline
\end{tabular}




\begin{tabular}{|c|c|c|c|c|c|c|}
\hline Source & Section & Requirement/Recommendation & APCD Requirement Applicability & D & Ad & APCD Requirement \\
\hline $\begin{array}{l}\text { ANSI/ANS- } \\
8.3 \text { (1997) }\end{array}$ & 5.1, part 4 & $\begin{array}{l}\text { The design of the system should be as simple as is } \\
\text { consistent with the objectives of ensuring reliable } \\
\text { actuation of the criticality alarm signal and } \\
\text { avoidance of false alarms. }\end{array}$ & $\begin{array}{l}\text { This recommendation is applicable to APCDs used to } \\
\text { augment NIMs in areas not normally occupied. }\end{array}$ & $\mathrm{D}$ & N/A & $\begin{array}{l}\text { The APCD design should be as } \\
\text { simple as is consistent with the } \\
\text { objectives of ensuring reliable } \\
\text { actuation of the criticality alarm } \\
\text { signal and avoidance of false alarms. }\end{array}$ \\
\hline \multirow[t]{2}{*}{$\begin{array}{l}\text { ANSI/ANS- } \\
8.3 \text { (1997) }\end{array}$} & \multirow[t]{2}{*}{5.2, part 1} & \multirow[t]{2}{*}{$\begin{array}{l}\text { All components of the system should be located or } \\
\text { protected to minimize damage in case of fire, } \\
\text { explosion, corrosive atmosphere, or other extreme } \\
\text { conditions. }\end{array}$} & \multirow{2}{*}{$\begin{array}{l}\text { This recommendation has limited applicability to APCDs } \\
\text { used to augment NIMs in area not normally occupied. An } \\
\text { APCD will be worn by personnel and is not expected to } \\
\text { survive excessively high temperature, explosion, severe } \\
\text { corrosive atmosphere or other extreme conditions. Personnel } \\
\text { entering environments involving extreme conditions (e.g., } \\
\text { corrosive atmosphere) will wear protective clothing and } \\
\text { must wear the APCD in a manner that protects it from such } \\
\text { conditions. }\end{array}$} & N/A & Ad & $\begin{array}{l}\text { The APCD shall be worn in a manner } \\
\text { that protects it from extreme } \\
\text { conditions. }\end{array}$ \\
\hline & & & & $\mathrm{D}$ & N/A & $\begin{array}{l}\text { The APCD should be designed to be } \\
\text { durable under normal conditions of } \\
\text { use. }\end{array}$ \\
\hline $\begin{array}{l}\text { ANSI/ANS- } \\
8.3 \text { (1997) }\end{array}$ & 5.2, part 2 & $\begin{array}{l}\text { The system should be designed to minimize the } \\
\text { potential for failure, including false alarms, due to } \\
\text { human error. }\end{array}$ & $\begin{array}{l}\text { This recommendation is applicable to APCDs used to } \\
\text { augment NIMs in areas not normally occupied. }\end{array}$ & N/A & Ad & $\begin{array}{l}\text { Personnel shall be instructed in } \\
\text { proper APCD use, available } \\
\text { functions, and actions to avoid false } \\
\text { alarms. }\end{array}$ \\
\hline $\begin{array}{l}\text { ANSI/ANS- } \\
8.3(1997)\end{array}$ & 5.2, part 3 & Major system components should be labeled. & $\begin{array}{l}\text { This recommendation is not applicable to APCDs, but to } \\
\text { fixed NIM systems. }\end{array}$ & N/A & N/A & N/A \\
\hline $\begin{array}{l}\text { ANSI/ANS- } \\
8.3 \text { (1997) }\end{array}$ & 5.3 & $\begin{array}{l}\text { The system should remain operational in the event } \\
\text { of seismic shock equivalent to the site-specific } \\
\text { design basis earthquake, or to the equivalent value } \\
\text { specified by the Uniform Building Code that applies } \\
\text { to the structure. }\end{array}$ & $\begin{array}{l}\text { This recommendation is not applicable to APCDs, but to } \\
\text { fixed NIM systems. In the event of seismic events, } \\
\text { personnel are trained to evacuate facility areas. }\end{array}$ & N/A & N/A & N/A \\
\hline
\end{tabular}




\begin{tabular}{|c|c|c|c|c|c|c|}
\hline Source & Section & Requirement/Recommendation & APCD Requirement Applicability & $\mathbf{D}$ & Ad & APCD Requirement \\
\hline \multirow[t]{3}{*}{\begin{tabular}{|l|} 
ANSI/ANS- \\
8.3 (1997)
\end{tabular}} & \multirow[t]{3}{*}{5.4} & \multirow[t]{3}{*}{$\begin{array}{l}\text { The system should be designed to provide a visible } \\
\text { or audible warning signal at some normally occupied } \\
\text { location to indicate system malfunction or the loss of } \\
\text { primary power. }\end{array}$} & \multirow{3}{*}{$\begin{array}{l}\text { This recommendation is applicable to APCDs used to } \\
\text { augment NIMs in areas not normally occupied. APCDs are } \\
\text { worn by the user and are generally equipped with a detector } \\
\text { failure, component failure, and low battery condition alarm. } \\
\text { APCDs are local and not remote units. When APCDs are } \\
\text { used to augment criticality accident alarm systems, each } \\
\text { individual within the area will be wearing at least one } \\
\text { APCD. } \\
\text { A minimum of two APCDs will be required in the area } \\
\text { requiring coverage. }\end{array}$} & $\mathrm{D}$ & $\mathrm{N} / \mathrm{A}$ & $\begin{array}{l}\text { APCDs should be designed to provide } \\
\text { an indication of system malfunction, } \\
\text { including a low battery condition. }\end{array}$ \\
\hline & & & & N/A & Ad & $\begin{array}{l}\text { APCD users in areas not normally } \\
\text { occupied shall be trained to evacuate } \\
\text { upon indication of system alarm, } \\
\text { system malfunction, or low battery } \\
\text { condition. }\end{array}$ \\
\hline & & & & N/A & Ad & $\begin{array}{l}\text { All individuals entering an area not } \\
\text { normally occupied shall be equipped } \\
\text { with an APCD. If only one person } \\
\text { enters such area, that person shall be } \\
\text { equipped with two APCDs. }\end{array}$ \\
\hline \begin{tabular}{|l|} 
ANSI/ANS- \\
8.3 (1997) \\
\end{tabular} & 5.5 & $\begin{array}{l}\text { The system shall be designed to produce the } \\
\text { criticality alarm signal within one-half second of } \\
\text { detector recognition of a criticality accident. }\end{array}$ & $\begin{array}{l}\text { This requirement is applicable to APCDs used to augment } \\
\text { NIMs in areas not normally occupied. APCDs must respond } \\
\text { to a step increase in radiation in a time frame similar to that } \\
\text { of regular NIM instruments in the annual NIM response test. }\end{array}$ & N/A & Ad & $\begin{array}{l}\text { APCDs must respond to a step } \\
\text { increase in radiation in a time frame } \\
\text { similar to that of regular NIM } \\
\text { instruments in the annual NIM } \\
\text { response test. }\end{array}$ \\
\hline \begin{tabular}{|l|} 
ANSI/ANS- \\
8.3 (1997)
\end{tabular} & 5.6 & $\begin{array}{l}\text { Criticality alarm systems shall be designed to } \\
\text { respond immediately to the minimum accident of } \\
\text { concern. For this purpose, in areas where material is } \\
\text { handled or processed with only nominal shielding, } \\
\text { the minimum accident may be assumed to deliver the } \\
\text { equivalent of an absorbed dose rate in free air of } 0.2 \\
\text { Gy/min ( } 20 \mathrm{rad} / \mathrm{min}) \text { at } 2 \text { meters from the reacting } \\
\text { material. The basis for a different minimum } \\
\text { accident of concern shall be documented. }\end{array}$ & $\begin{array}{l}\text { This requirement is applicable in a limited sense to APCDs } \\
\text { used to augment NIMs in areas not normally occupied. The } \\
\text { minimum accident of concern is used in establishing fixed } \\
\text { NIM instrument placement. Since APCDs are worn by an } \\
\text { individual, fixed placement consideration is not required. } \\
\text { However, the alarm setpoint should be set low enough to } \\
\text { detect doses of concern to workers from a criticality } \\
\text { accident. }\end{array}$ & N/A & Ad & $\begin{array}{l}\text { APCD alarm setpoints should be set } \\
\text { high enough above background to } \\
\text { minimize false alarms yet low enough } \\
\text { to detect doses of concern from } \\
\text { criticality accidents. }\end{array}$ \\
\hline
\end{tabular}


WESTINGHOUSE SAVANNAH RIVER COMPANY T\&QS/NUCLEAR SAFETY
N-TRT-G-00001

Rev. 0

Page 20 of 29

\begin{tabular}{|c|c|c|c|c|c|c|}
\hline Source & Section & Requirement/Recommendation & APCD Requirement Applicability & D & Ad & APCD Requirement \\
\hline $\begin{array}{l}\text { ANSI/ANS- } \\
8.3(1997)\end{array}$ & 5.7 .1 & $\begin{array}{l}\text { Criticality alarm systems shall be designed so that } \\
\text { alarm actuation shall occur as a result of the } \\
\text { minimum duration transient. It may be assumed that } \\
\text { the minimum duration of the radiation transient is } 1 \\
\text { msec. }\end{array}$ & $\begin{array}{l}\text { This requirement is applicable to APCDs used to augment } \\
\text { NIMs in areas not normally occupied. Testing shall } \\
\text { demonstrate that APCDs are capable of detecting short } \\
\text { duration transients (approx. } 1 \mathrm{msec} \text { ). }\end{array}$ & $\mathrm{D}$ & N/A & $\begin{array}{l}\text { Test results shall be available to } \\
\text { demonstrate that APCDs produce an } \\
\text { alarm when exposed to a short } \\
\text { duration radiation transient (approx. } 1 \\
\text { msec). }\end{array}$ \\
\hline $\begin{array}{l}\text { ANSI/ANS- } \\
8.3(1997)\end{array}$ & 5.7.2, part 1 & $\begin{array}{l}\text { The alarm trip point should be set high enough to } \\
\text { minimize the probability of an alarm from sources } \\
\text { other than criticality. }\end{array}$ & $\begin{array}{l}\text { This recommendation is applicable to APCDs used to } \\
\text { augment NIMs in areas not normally occupied. }\end{array}$ & N/A & $\mathrm{Ad}$ & $\begin{array}{l}\text { The APCD alarm setpoint should be } \\
\text { set sufficiently above background to } \\
\text { minimize false alarms. }\end{array}$ \\
\hline $\begin{array}{l}\text { ANSI/ANS- } \\
8.3 \text { (1997) }\end{array}$ & 5.7.2, part 2 & $\begin{array}{l}\text { The level shall be set low enough to detect the } \\
\text { minimum accident of concern. }\end{array}$ & $\begin{array}{l}\text { This requirement is applicable in a limited sense to APCDs } \\
\text { used to augment NIMs in areas not normally occupied. The } \\
\text { minimum accident of concern is used in establishing fixed } \\
\text { NIM placement. Since APCDs are worn by the user, fixed } \\
\text { placement consideration is not required. However, the alarm } \\
\text { setpoint should be set low enough to detect doses of concern } \\
\text { from criticality accidents. }\end{array}$ & N/A & Ad & $\begin{array}{l}\text { APCD alarm setpoints should be set } \\
\text { high enough above background to } \\
\text { minimize false alarms yet low enough } \\
\text { to detect doses of concern from } \\
\text { criticality accidents. }\end{array}$ \\
\hline $\begin{array}{l}\text { ANSI/ANS- } \\
8.3 \text { (1997) }\end{array}$ & 5.8, part 1 & $\begin{array}{l}\text { The spacing of detectors shall be consistent with the } \\
\text { selected alarm trip point and with the detection } \\
\text { criterion. }\end{array}$ & $\begin{array}{l}\text { This requirement is not applicable to APCDs. This } \\
\text { requirement is applicable to fixed NIM installations. }\end{array}$ & N/A & N/A & N/A \\
\hline $\begin{array}{l}\text { ANSI/ANS- } \\
8.3 \text { (1997) }\end{array}$ & 5.8, part 2 & $\begin{array}{l}\text { The location and spacing of detectors should be } \\
\text { chosen to minimize the effect of shielding by } \\
\text { massive equipment or materials. Shielding from } \\
\text { low-density materials of construction, such as wood } \\
\text { framing, thin interior walls, hollow brick tiles, etc., } \\
\text { may be disregarded. }\end{array}$ & $\begin{array}{l}\text { This requirement is not applicable to APCDs. This } \\
\text { requirement is applicable to fixed NIM installations. }\end{array}$ & N/A & N/A & N/A \\
\hline
\end{tabular}




\begin{tabular}{|c|c|c|c|c|c|c|}
\hline Source & Section & Requirement/Recommendation & APCD Requirement Applicability & D & Ad & APCD Requirement \\
\hline $\begin{array}{l}\text { ANSI/ANS- } \\
8.3(1997)\end{array}$ & 6.1 & $\begin{array}{l}\text { Initial tests, inspections and checks of the system } \\
\text { shall verify that the fabrication and installation were } \\
\text { made in accordance with design plans and } \\
\text { specifications. }\end{array}$ & $\begin{array}{l}\text { This requirement is applicable to APCDs. APCDs shall be } \\
\text { inspected when received from offsite to ensure that the } \\
\text { correct APCD has been received and fabricated correctly. }\end{array}$ & N/A & Ad & $\begin{array}{l}\text { APCDs shall be inspected when } \\
\text { received from offsite to ensure that the } \\
\text { correct APCD has been received and } \\
\text { that it is fabricated correctly. }\end{array}$ \\
\hline $\begin{array}{l}\text { ANSI/ANS- } \\
8.3 \text { (1997) }\end{array}$ & 6.2 & $\begin{array}{l}\text { Following modifications or repairs, or events that } \\
\text { call the system performance into question, there } \\
\text { shall be tests and inspections adequate to } \\
\text { demonstrate system operability. }\end{array}$ & $\begin{array}{l}\text { This requirement is applicable to APCDs used to augment } \\
\text { NIMs in areas not normally occupied. }\end{array}$ & N/A & Ad & $\begin{array}{l}\text { APCDs shall be calibrated and tested } \\
\text { prior to being returned to service } \\
\text { following any modifications, repairs } \\
\text { or events that call the APCD's } \\
\text { performance into question. }\end{array}$ \\
\hline $\begin{array}{l}\text { ANSI/ANS- } \\
8.3 \text { (1997) }\end{array}$ & 6.3 , part 1 & $\begin{array}{l}\text { System response to radiation shall be measured } \\
\text { periodically to confirm continuing instrument } \\
\text { performance. }\end{array}$ & $\begin{array}{l}\text { This requirement is applicable to APCDs used to augment } \\
\text { NIMs in areas not normally occupied. Periodically tests } \\
\text { shall ensure continued instrument performance. }\end{array}$ & N/A & Ad & $\begin{array}{l}\text { APCDs shall be periodically tested to } \\
\text { ensure continued instrument response } \\
\text { to radiation. }\end{array}$ \\
\hline $\begin{array}{l}\text { ANSI/ANS- } \\
8.3 \text { (1997) }\end{array}$ & 6.3 , part 2 & $\begin{array}{l}\text { The test interval should be determined on the basis } \\
\text { of experience. In the absence of experience, tests } \\
\text { should be performed at least monthly. }\end{array}$ & $\begin{array}{l}\text { This requirement is applicable to APCDs used to augment } \\
\text { NIMs in areas not normally occupied. APCDs shall be } \\
\text { tested monthly unless historical data suggests that less } \\
\text { frequent testing is sufficient. }\end{array}$ & N/A & Ad & $\begin{array}{l}\text { APCDs shall be tested monthly unless } \\
\text { historical data suggests that less } \\
\text { frequent testing is sufficient. }\end{array}$ \\
\hline $\begin{array}{l}\text { ANSI/ANS- } \\
8.3 \text { (1997) }\end{array}$ & 6.3 , part 3 & Records of tests shall be maintained. & $\begin{array}{l}\text { This requirement is applicable to APCDs used to augment } \\
\text { NIMs in areas not normally occupied. }\end{array}$ & N/A & Ad & $\begin{array}{l}\text { The records of tests, calibrations and } \\
\text { maintenance for each APCD shall be } \\
\text { maintained. }\end{array}$ \\
\hline $\begin{array}{l}\text { ANSI/ANS- } \\
8.3 \text { (1997) }\end{array}$ & 6.3 , part 4 & $\begin{array}{l}\text { System designs may incorporate self-checking } \\
\text { features to automate portions of this testing. }\end{array}$ & $\begin{array}{l}\text { This permission statement is applicable to APCDs used to } \\
\text { augment NIMs in areas not normally occupied. APCDs may } \\
\text { be equipped with self-checking features such as component } \\
\text { testing, low battery condition, etc. }\end{array}$ & N/A & Ad & $\begin{array}{l}\text { APCDs with self-checking features (if } \\
\text { applicable) shall be tested } \\
\text { periodically in conjunction with other } \\
\text { testing. }\end{array}$ \\
\hline $\begin{array}{l}\text { ANSI/ANS- } \\
8.3 \text { (1997) }\end{array}$ & 6.4 , part 1 & The entire alarm system shall be tested periodically. & $\begin{array}{l}\text { This requirement is not applicable to APCDs. This } \\
\text { requirement is applicable to fixed NIM systems to ensure } \\
\text { that all components of the overall system (e.g., remote bells) } \\
\text { are functional. }\end{array}$ & N/A & N/A & N/A \\
\hline $\begin{array}{l}\text { ANSI/ANS- } \\
8.3 \text { (1997) }\end{array}$ & 6.4 , part 2 & $\begin{array}{l}\text { Each signal generator should be tested at least } \\
\text { annually. }\end{array}$ & $\begin{array}{l}\text { This recommendation is applicable to APCDs used to } \\
\text { augment NIMs in areas not normally occupied. APCDs shall } \\
\text { be tested at least annually to ensure audible alarm function. }\end{array}$ & N/A & Ad & $\begin{array}{l}\text { APCDs shall be tested at least } \\
\text { annually to ensure that the audible } \\
\text { alarm is functional. }\end{array}$ \\
\hline
\end{tabular}


WESTINGHOUSE SAVANNAH RIVER COMPANY T\&QS/NUCLEAR SAFETY
N-TRT-G-00001

Rev. 0

Page 22 of 29

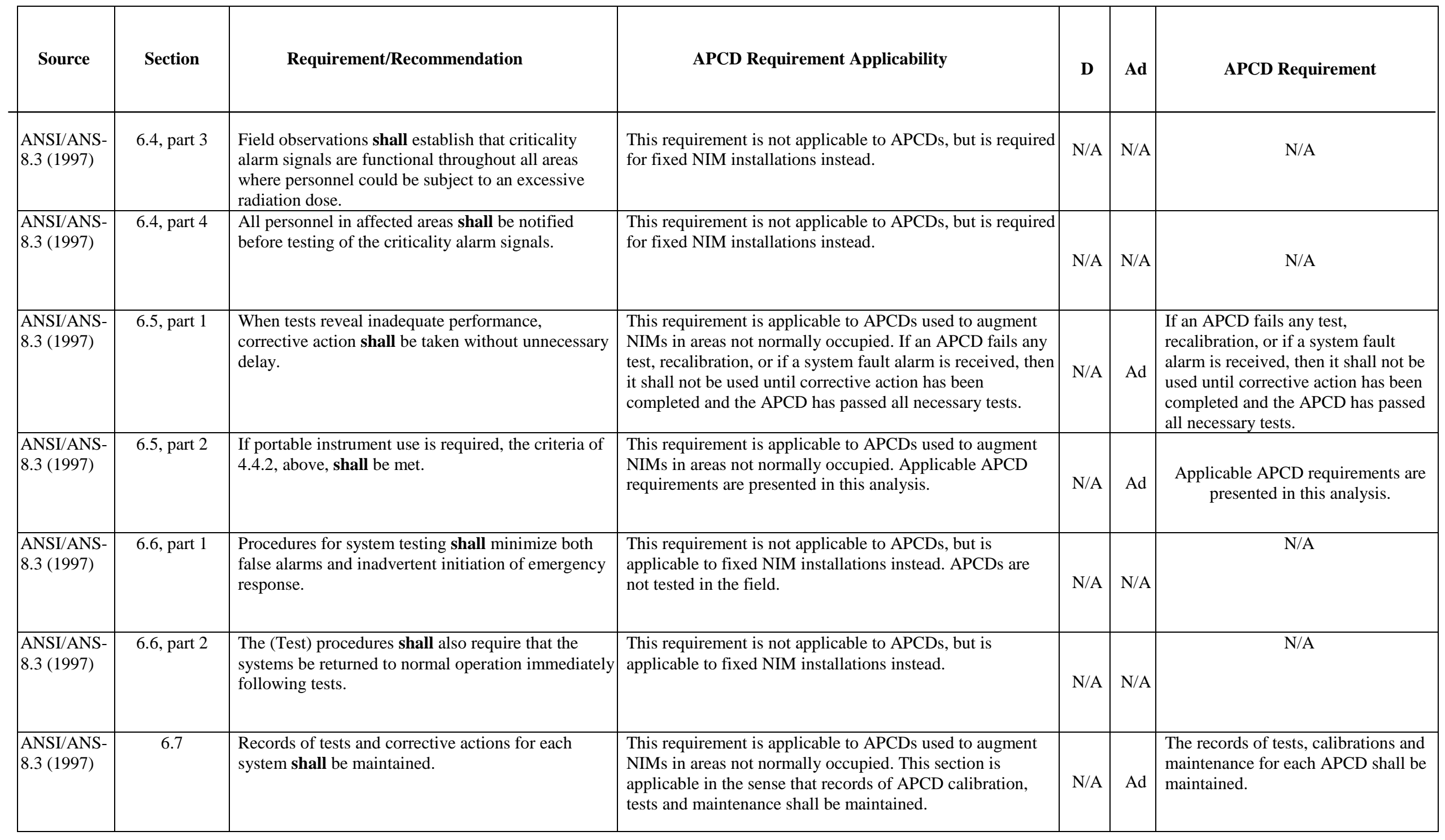


WESTINGHOUSE SAVANNAH RIVER COMPANY T\&QS/NUCLEAR SAFETY
N-TRT-G-00001

Rev. 0

Page 23 of 29

\begin{tabular}{|c|c|c|c|c|c|c|}
\hline Source & Section & Requirement/Recommendation & APCD Requirement Applicability & D & Ad & APCD Requirement \\
\hline $\begin{array}{l}\text { ANSI/ANS- } \\
8.3 \text { (1997) }\end{array}$ & 7.1 & $\begin{array}{l}\text { Instructions regarding response to criticality alarm } \\
\text { signals shall be posted at strategic locations within } \\
\text { areas requiring alarm coverage. }\end{array}$ & $\begin{array}{l}\text { This requirement is applicable to APCDs used to augment } \\
\text { NIMs in areas not normally occupied. However, instructions } \\
\text { are typically included in training and documented in } \\
\text { procedures }\end{array}$ & N/A & Ad & $\begin{array}{l}\text { Personnel shall be trained in the } \\
\text { proper response to APCD alarms. } \\
\text { Upon exiting areas not normally } \\
\text { occupied, regular facility evacuation } \\
\text { routes shall be followed. }\end{array}$ \\
\hline $\begin{array}{l}\text { ANSI/ANS- } \\
8.3 \text { (1997) }\end{array}$ & 7.2 & $\begin{array}{l}\text { Guidance for training of employees and visitors, and } \\
\text { for conduct of criticality alarm drills, is provided in } \\
\text { ANSI/ANS-8.19-1996. }\end{array}$ & $\begin{array}{l}\text { This statement is applicable to APCDs used to augment } \\
\text { NIMs in areas not normally occupied. Employees and } \\
\text { visitors who utilize APCDs shall be trained in their use and } \\
\text { in protective actions to be taken upon alarm. }\end{array}$ & N/A & Ad & $\begin{array}{l}\text { Employees and visitors who utilize } \\
\text { APCDs shall be trained in their use } \\
\text { and in protective actions to be taken } \\
\text { upon alarm. }\end{array}$ \\
\hline
\end{tabular}




\subsection{Definition of Not Normally Occupied}

As indicated in Section 1.0, and in compliance with ANSI/ANS-8.3-1997, the objective of this report is to provide a basis for the use of APCDs as portable instruments to augment facility NIM systems in areas not normally occupied by personnel. However, the term "not normally occupied" is not defined in ANSI/ANS8.3-1997. Therefore, other Standards in which occupancy is a concern were searched for uses of "not normally occupied" and other associated terms.

Several National Fire Protection Association Standards (NFPA) contain information related to "not normally occupied", "occupied", "occupiable stories", and "unmanned space" that may be used to develop a definition of "not normally occupied" applicable to the use of APCDs to augment facility NIM systems. ${ }^{3}$ The NFPA 301 definition of "unmanned space" best fits the concept of not normally occupied as intended to be used by WSRC. Such unmanned spaces are only occupied for limited periods, on the order of seven days per year. The "occupiable story" concept in The Life Safety Code, NFPA 101, provides similar guidance. Occupiable stories, which are dedicated to mechanical equipment, may require entry about seven days per year to perform maintenance. The inherent assumption for either the unmanned space or the occupiable story is that entry into such areas is infrequent and is of relatively short duration. In addition, the NFPA definition of "occupied" (i.e., > 10 occupants) suggests a general upper limit of occupants for areas designated as not normally occupied (i.e., < 10 occupants).

Using the information above from the NFPA Standards, the Group to Recommend Alternatives to NIM Detectors (see section 1.0) developed the following definition:

Not Normally Occupied - An area for which entry is controlled and recommended occupancy is limited to 168 hours per year, not to exceed 40 hours per month, and the number of occupants is limited to 10 at any given time. Facility management may request an extension of occupancy time and/or number of occupants, subject to local Criticality Safety Committee concurrence.

The use of APCDs to augment facility NIM systems in areas not normally occupied by personnel shall be subject to the definition above.

\subsection{APCD Design Criteria and APCDs That Meet the Criteria}

Table 2 contains a compilation of all APCD design criteria identified from the Table 1 analysis. Table 2 also documents the compliance of Siemens EPD/Mk2 and EPD-N devices in meeting the design criteria.

Table 2. APCD Design Criteria and Siemens EPD/Mk2 and EPD-N Compliance

\begin{tabular}{|c|c|}
\hline Design Criterion & $\begin{array}{l}\text { Siemens EPD/Mk2 and } \\
\text { EPD-N Compliance }\end{array}$ \\
\hline 1. APCDs shall resist radio frequency and electrostatic interference & Yes - Reference 4 \\
\hline 2. APCDs shall be capable of alarming on cumulative dose & Yes - Reference 5 \& 6 \\
\hline $\begin{array}{l}\text { 3. APCDs shall provide an audible signal that is recognized as requiring prompt } \\
\text { evacuation. }\end{array}$ & Yes - Reference 5 \& 6 \\
\hline $\begin{array}{l}\text { 4. Documented test results shall demonstrate prompt and automatic APCD alarm } \\
\text { response to a simulated criticality accident. }\end{array}$ & Yes - Reference 7 \\
\hline $\begin{array}{l}\text { 5. APCDs shall provide a signal to the individual carrying the instrument that is } \\
\text { sufficiently long to get their attention. }\end{array}$ & Yes - See Appendix A \\
\hline
\end{tabular}


Table 2. APCD Design Criteria and Siemens EPD/Mk2 and EPD-N Compliance

6. APCD audio alarm shall be loud enough to be heard by the individual wearing the device

Yes - Reference 5, 6, \& Appendix A $(2$

7. APCD audio alarm sound level should not be loud enough to cause hearing damage.

Yes - Reference 5, 6, \& Appendix A

8. APCDs should include the ability to use earpieces or provide vibration alarms.

9. APCDs shall be capable of alerting the user to a low battery condition.

Yes - Reference 5 \& 6

10. Documented tests shall demonstrate APCD capability to alarm in radiation fields typical of a criticality accident.

Yes - Reference 5 \& 6



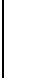

11. APCDs should not require frequent servicing, lubrication, or cleaning.

12. APCD design should minimize effects of non-use, deterioration, and other conditions (e.g., RF and electrostatic interference).

Yes - Reference 5 \& 6; also, Siemens EPDs have been used at SRS for several years. Historical information verifies that these devices do not require frequent servicing, lubrication, or cleaning.

Yes - Reference 4; also, Siemens EPDs have been used at SRS for several years. Historical information verifies that these devices are not affected by non-use and have not deteriorated.

Yes - Reference 5 and 6; also, Siemens EPDs have

13. APCD design should be a simple as is consistent with the objectives of ensuring actuation of the criticality alarm and avoidance of false alarms.

been used at SRS for several years. Historical information verifies that these devices are simple and straightforward to use. 
Table 2 APCD Design Criteria and Siemens EPD/Mk2 and EPD-N Compliance

\begin{tabular}{|l|c|}
\hline $\begin{array}{l}\text { 14. APCDs should be designed to minimize the potential for failure, including } \\
\text { deactivation and false alarms, due to human error. }\end{array}$ & $\begin{array}{c}\text { Yes - Reference 5 \& 6; also, } \\
\text { Siemens EPDs have been } \\
\text { used at SRS for several } \\
\text { years. Historical information } \\
\text { verifies that these devices } \\
\text { are designed to resist human } \\
\text { failure. }\end{array}$ \\
\hline $\begin{array}{l}\text { 15. APCDs shall provide an indication of system malfunction, including low battery } \\
\text { condition. }\end{array}$ & Yes - Reference 5 \& 6 \\
\hline $\begin{array}{l}\text { 16. Documented test results shall demonstrate that the APCDs produce an alarm when } \\
\text { exposed to a short duration radiation transient (approx. 1 msec). }\end{array}$ & Yes - Reference 7 \\
\hline $\begin{array}{l}\text { 17. APCDs shall be designed to produce an alarm within } 4 \text { seconds of detector } \\
\text { recognition of a step increase in dose rate greater than 10\% over the setpoint. }\end{array}$ & Yes - Appendix A \\
\hline
\end{tabular}

\subsection{Administrative Requirements for APCD Use}

Table 3 contains a compilation of all APCD design criteria identified from the Table 1 analysis. These administrative requirements must be incorporated into Facility, Radcon, or site-level procedures as appropriate prior to the use of APCDs to augment facility NIM systems in areas not normally occupied.

\section{Table 3. Administrative Requirements for APCD Use}

1. APCD cumulative dose alarm shall be set high enough to avoid false alarms while retaining the capability to detect unsafe dose to workers. GRAND recommends that APCD cumulative dose alarm be set a 1 rem.

2. APCD alarm setpoints should be set sufficiently above background to minimize false alarms. GRAND recommends that the dose rate alarm be set a minimum of $30 \mathrm{mr} / \mathrm{hr}$, or $10 \%$, above expected background, whichever is greater, and the APCD cumulative dose alarm be set a 1 rem.

3. Radcon procedures for calibration of Siemens EPDs used for dose logging shall be applied to Siemens EPD/MK-2 or EPD-N instruments used as APCDs to ensure functionality and reliability. Siemens EPD/MK-2 or EPD-N instruments used as APCDs should be marked in such a way that they can be distinguished from Siemens EPDs used for dose logging.

4. Facilities/projects using APCDs shall have an approved training program/procedure on APCD use.

5. Personnel wearing APCDs shall be trained in their use and in evacuation, including evacuation for instrument malfunction or a low battery condition.

6. If protective actions other than evacuation are necessary, they shall also be specified in training.

7. Personnel shall be capable of distinguishing the APCD alarm from other alarms.

8. Personnel shall be trained and have a means to contact the appropriate control room after evacuation so that the event is logged and other facility emergency actions can be taken as necessary. 
Table 3. Administrative Requirements for APCD Use

9. When using APCDs in high noise areas, the APCDs shall be equipped with earpieces and/or vibration alarms.

10. APCD pre-alarms, if provided, should be disabled.

11. Facilities/projects shall develop the necessary procedures to ensure that these administrative requirements are met.

12. Personnel shall be trained to evacuate an area intended for APCD use upon APCD low battery condition or device malfunction.

13. APCD batteries shall be changed or re-charged on a regular basis.

14. A minimum offset distance from the edge of a designated potential criticality accident location (e.g., edge of tank) shall be established to ensure APCD functionality. GRAND recommends a minimum offset distance of 3 meters (10 feet).

15. APCDs shall not be re-used after exposure to excessive radiation fields, such as from a criticality accident or a simulated criticality test.

16. APCDs shall be worn in a manner that protects it from extreme environments (e.g., under protective clothing).

17. Personnel shall be instructed in proper APCD use, available functions, and actions to avoid false alarms.

18. APCDs must respond to a step increase in radiation in a time frame similar to that of regular NIM instruments in the annual NIM response test.

19. APCDs shall be calibrated and tested prior to being returned to service following any modifications, repairs or events that call APCD performance into question.

20. APCDs shall be periodically calibrated and tested to ensure continued appropriate instrument response to radiation. This test requirement and the test requirement in item 21 may be combined at the discretion of the testing organization(s).

21. APCD shall be tested monthly unless historical data suggests that less frequent testing is sufficient.

22. The records of tests, calibrations and maintenance for each APCD shall be maintained.

23. APCDs with self-checking features (if available) shall be tested periodically in conjunction with other testing.

24. APCDs shall be tested at least annually to ensure that the audible alarm is functional.

25. If an APCD fails any test, recalibration, or if a system fault is received, then it shall not be used until corrective action has been completed and the APCD has passed all necessary tests.

26. Upon exiting area not normally occupied in the event of an APCD alarm, regular facility NIM evacuation routes shall be followed.

27. Visitors who use APCDs shall be trained in their use.

28. All personnel entering a not normally occupied 12 rad zone area shall be equipped with an APCD. If only one person enters such area, that person shall be equipped with two APCDs. 


\subsection{References}

1. DOE Order 420.1A, Facility Safety, Att. 2, para. 4.3.2.e, U. S. Department of Energy, 5/20/2002.

2. ANSI/ANS-8.3-1997, Criticality Accident Alarm System, published by the American Nuclear Society, 5/28/1997.

3. WSMS-SAE-M-03-0076, Modified NIM Protection for Areas that are Not Normally Occupied, A. A. Coutts, Washington Safety Management Solutions, 4/21/2003.

4. Evaluation of Siemens Environmental Systems Model Mk-2 Electronic Personal Dosimeter, T. E. Bratvold, Battelle Memorial Institute, July 2001.

5. Siemens Electronic Personal Dosimeter (EPD Mk2) Technical Handbook, 611/HB/4052/000, Siemens Plc., 1999.

6. Siemens Neutron Sensitive Electronic Personal Dosimeter (EPD-N Mk2.0) Technical Handbook, 611/HB/44335/000, Siemens Plc., 9/4/2000.

7. Testing of Siemens Electronic Personal Dosimeters (EPD) in Simulated Criticality Conditions, J. F. Coleman, Siemens Commercial-In-Confidence Paper, 5/25/2000. 
APPENDIX A

WSRC Testing of Siemens EPD-N APCDs

\section{Test Details:}

Date: $\mathbf{3 / 1 1 / 2 0 0 3}$

Personnel Performing Test: J. W. McMahan (Maintenance Engineering, Site NIM Engineer) and T. R. Sullivan (Health Physics Technology)

\section{Purpose of Test:}

To test Siemens EPD-N MK 2 instruments to a step increase in dose rate greater than $10 \%$ over the setpoint and observe response time to alarm signal;

To observe duration of audible alarm signal;

To qualitatively observe loudness of alarm signal;

\section{Test Description:}

Two Siemens EPD-N Mk 2 instruments with neutron detection capabilities were subjected to a step increase radiation from the Health Physics gamma irradiator. This facility exposes a Cs 137 source in a short time for evaluation of the speed of response a detector system exhibits. Using several repetitive exposures, the two samples responded similarly and repeatably to the source.

The reason for these tests was to evaluate the effect of data processing as described in the vendor literature, which suggested some time might be lost because a sampling scheme with an unacceptably long several second interval was in use to conserve power. However, the time from beginning of exposure to alarm sound was measured and resulted in consistent 2.5 to 3.5 second intervals, proving there was no meaningful sampling influence. The time response of the Siemens EPD-N Mk 2 was determined to be acceptable for personal criticality alarm application.

The audible alarm sounded for several seconds and it was noted that the instrument settings could be easily adjusted such that the alarm could be made to latch (i.e., sound continuously). Thus, the duration of the signal was judged acceptable.

The loudness of the audible alarm was qualitatively judged to be sufficiently loud to alert the wearer, yet without being loud enough to cause hearing damage. 